\title{
Ineffectiveness of Apistan ${ }^{\circledR}$ treatment against the mite Varroa jacobsoni Oud in several districts of Lombardy (Italy)
}

\author{
M Lodesani ${ }^{1}$, M Colombo $^{2}$, M Spreafico $^{3}$ \\ 1 Istituto Nazionale di Apicoltura, via S Giacomo, 9, 40126 Bologna; \\ 2 Istituto di Entomologia agraria, Università degli Studi, via Celoria, 2, 20133 Milan; \\ ${ }^{3}$ Laboratorio Apistico, Unione Regionale tra le Associazioni dei Produttori Apistici della Lombardia, \\ via Celoria, 2, 20133 Milan, Italy
}

(Received 22 August 1994; accepted 22 December 1994)

\begin{abstract}
Summary - The effectiveness of Apistan ${ }^{\circledR}$ (Sandoz) was tested in 8 apiaries (78 colonies) in some districts of Lombardy (north Italy) during 1993. The strips were left for $22 \mathrm{~d}$ in colonies in which the queens were caged inside the hives. On the 24th day, a treatment with $5 \mathrm{ml} / \mathrm{comb}$ of Perizin ${ }^{\mathbb{P}}$ was given. The

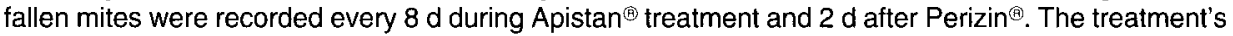
average effectiveness varied greatly from apiary to apiary ( $\min 4 \%$, max $89.5 \%$ ). In Lombardy, where quite a high mortality of colonies (caused by varroosis) was reported by some beekeepers during autumn 1992, the average effectiveness of the treatment with Apistan ${ }^{\circledR}$ was $44.5 \%$. The results indicate different levels of resistance of Varroa jacobsoni to fluvalinate.
\end{abstract}

Apis mellifera / Varroa jacobsoni / fluvalinate / effectiveness / resistance

\section{INTRODUCTION}

Since Varroa jacobsoni Oud was first detected in Italy (Barbattini, 1981) various products for controlling Varroa, such as Folbex VA ${ }^{\oplus}$, Apitol ${ }^{\oplus}$, Apivar ${ }^{\circledR}$ and Perizin ${ }^{\circledR}$ have been registered (in that order) by the Italian Ministry of Health. Nevertheless, the strategies and legally adopted drugs have often been complemented or replaced with other products or treatments by operators on their own initiative. Products based on fluvalinate $\left(\right.$ Klartan $\left.^{\circledR}\right)$ and amitraz (Taktic $\left.{ }^{(}{ }^{(}\right)$, Bumetran ${ }^{\circledR}$ and Edrizar ${ }^{\circledR}$ ) are not authorized for use in beekeeping but were widely administered using a variety of methods (Frilli, 1989).

In 1989, these practices were largely curtailed by the registration of Apistan ${ }^{\circledR}$, especially in regions such as Lombardy where the product was freely distributed to all beekeepers. This began in 1990 as part of territorial programmes to combat varroosis. 
Since 1992, some beekeepers and representatives of national organisations have voiced doubts about the effectiveness of Apistan $\left.{ }^{(}\right)$in controlling varroosis, on the basis of evidence from direct observations. In some regions of Italy, cases of colony mortality due to varroosis in apiaries regularly treated with Apistan ${ }^{\circledR}$ have been found. The problem was first officially noted in northern Italy in the district of Bergamo, and confirmed by the Health Department in 1992 (Loglio and Plebani, 1992; Loglio, 1993). During the summer of the same year, a high mortality rate of hives, sometimes of entire apiaries, was recorded in other provinces of Lombardy.

Some of the cases of colony mortality may be ascribed to the incorrect use of the product by beekeepers (Barbattini and Greatti, 1992; Frediani, 1993; Watkins, 1993). However, recurrent reports by reliable operators, together with the spread of the problem and the high mortality rate called for a study to investigate if, in fact, there was some resistance of Varroa to fluvalinate.

\section{MATERIALS AND METHODS}

Tests were conducted in 1993, between the end of April and the beginning of June, on 78 hives in 8 different apiaries situated in Lombardy (fig 1). Certain districts of Lombardy were chosen to carry out the tests. There were 2 reasons for this choice: 1) a programme of varroosis control, based on the use of Apistan ${ }^{\circledR}$ alone and supported by special public funds had been conducted in these areas for 3 years; and 2) high colony mortality rates had been observed in these regions.

In the previous year (1992), 4 of the 8 apiaries had been treated exclusively with Apistan $^{\circledR}$ (group A, fig 1); the other 4 were treated with Apistan ${ }^{(1)}$ and either amitraz or Perizin ${ }^{\circledR}$ (group B). Hives in Emilia-Romagna were initially included as a control group, but the average number of fallen Varroa mites detected with the treatments was lower than 10 and these hives were therefore omitted.

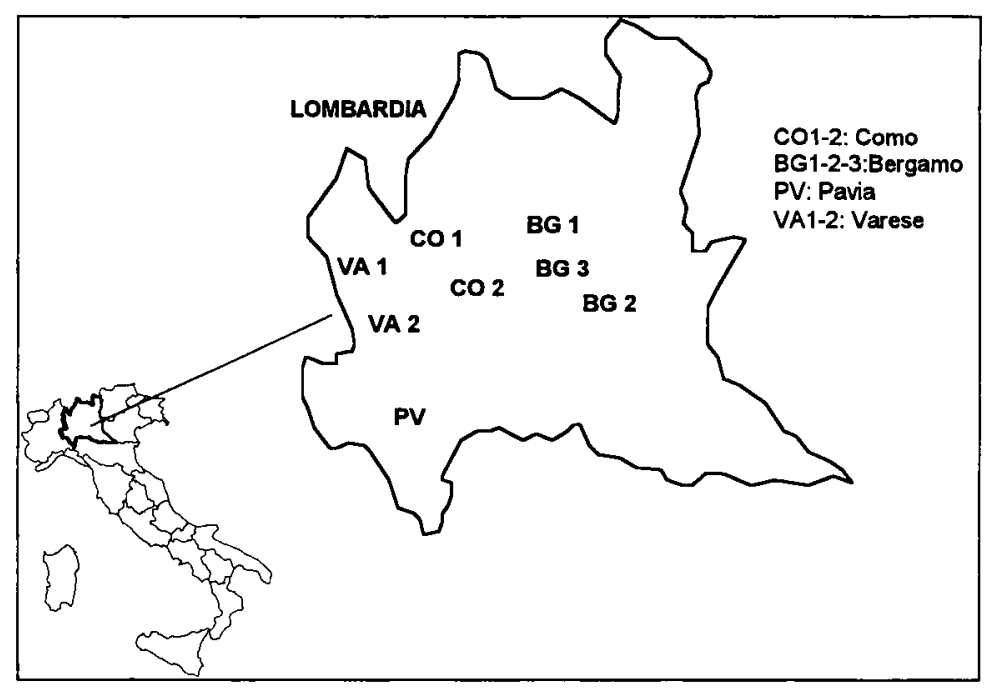

Fig 1. Location and situation of the apiaries in which the tests were carried out. Group A (VA1, CO1, BG1, BG2): colonies treated exclusively with Apistan ${ }^{\oplus}$ in 1992 in areas where hive mortality for varroosis was recorded; group B (CO2, PV, VA2, BG3): colonies treated in 1992 with Apistan ${ }^{\circledR}$ and Perizin ${ }^{\circledR}$ (CO2, PV) or with Apistan ${ }^{\oplus}$ and amitraz (VA2, BG3), in areas where hive mortality for varroosis was recorded. 
For this test, only colonies with similar amounts of brood, bees and stored honey were chosen. Two strips of Apistan $\left.{ }^{(}\right)$(Lot No 91120191, produced in USA in December 1992) were placed in each hive the first day of the test (day $t$ ) and left for $22 \mathrm{~d}$.

Egg laying was interrupted from day $t$ until day $t+16$ to determine the number of mites surviving after treatment with a systemic product that, to be fully effective, requires the absence of capped brood. For this purpose, the queen of each hive was placed in a queen-cage, placed near the brood area of a central comb. Two days after the removal of the Apistan ${ }^{\circledR}$ strips $(t+24)$, when no sealed brood was present in the colonies, a Perizin ${ }^{\circledR}$ treatment was given to each colony by delivering $5 \mathrm{ml}$ of emulsion to each honeycomb crowded with bees.

Every $8 \mathrm{~d}$ during the treatment with Apistan and $2 \mathrm{~d}$ after the treatment with Perizin ${ }^{\circledR}$, we counted all the mites captured on the paper sheets smeared with vaseline at the bottom of the hives. The effectiveness of the Apistan ${ }^{\circledR}$ treatment was calculated according to the formula:

$$
\begin{aligned}
& \text { fallen mites with Apistan }{ }^{(\circledR)} \\
& \% \text { eff }=\text { - } \times 100 \\
& \text { fallen mites with both treatments }
\end{aligned}
$$

The average effectiveness of each apiary was calculated to show the situation of the whole population.

The intense activity of the bees due to favourable environmental conditions (daytime temperatures always greater than $15^{\circ} \mathrm{C}$ in all the tested areas, length of the photoperiod and abundant blooming) during the period in which the tests were conducted, allowed optimal distribution of the active compound within the colonies (Milani and Barbattini, 1988; Borneck and Merle, 1989; De Ruijter and Van Den Eijnde, 1989; Llorente Martinez, 1989). The interruption of brood production further facilitated contact of fluvalinate with the mites. For this reason, the time the strips remained in the colonies was reduced from the 6-10 weeks recommended by the company to $22 \mathrm{~d}$. The intense nectar-collecting activity during the test reduced the risk of reinfestation through robbing. Furthermore, it is possible that some mites that survived the treatment with Apis$\tan ^{\circledR}$ could also have survived a single treatment with Perizin ${ }^{\ominus}$ (Milani and Barbattini, 1988). Thus, the data of Apistan ${ }^{(1)}$ effectiveness could be overvalued in some cases.

\section{RESULTS}

The hives showed notable differences in the rate of infestation. This varied from a minimum of 1 (CO2, VA2) to a maximum of 5700 (BG2) mites per colony (table I). Even within the individual apiaries, the degree of infestation was very variable, with an SD often higher than the mean (CO2, VA2). A notable variability in the efficacy values was observed in the colonies of the apiaries of both groups (fig 2). This was particularly evident in the VA1 apiary ( $\min 0 \%, \max$ $99.1 \%$ ) and in the PV apiary ( $\min 0.6 \%$, max $92.6 \%$ ). Only in 16 of the 78 colonies tested yielded an effectiveness greater than $95 \%$.

In the apiaries of group A the effectiveness ranged from a minimum of $4 \%$ in $B G 1$ (with values between 1.1 and $8 \%$ ) to a maximum of $64.1 \%$ in BG2 (24.2-98.8\%). In group B, a lower average effectiveness was recorded in the PV (mean $10.4 \%, \min 0.6 \%$, $\max 92.6 \%$ ) and BG3 apiaries (mean $43.1 \%, \min 25.2 \%, \max 53.9 \%$ ) compared to that obtained in the $\mathrm{CO} 2$ (mean $89.5 \%$, $\min 52.6 \%, \max 100 \%$ ) and VA2 apiaries (mean $67.4 \%, \min 59.3 \%, \max 100 \%$ )

\section{DISCUSSION}

The average efficacy by apiary was lower than that reported by both Italian (Arculeo et al, 1989: 100\%; Barbattini et al, 1989: 92.3\%; Frilli et al, 1992: 92.3\%; Greatti et al, 1992/93: 99.7\%; Arculeo et al, 1993: 92.7-98.7\%) and foreign authors (Llorente Martinez et al, 1989: 99.33\%; Borneck and Merle, 1990: 99.38-99.72\%; Ferrer-Dufol et al, 1991: 100\%). According to Lendaro and Tonelli (1985), an adequate therapeutic efficacy must be more than $95 \%$, a value which was found in only $20.5 \%$ of the tested colonies distributed evenly throughout the apiaries. 
Table I. Average number of fallen mites with Apistan ${ }^{\circledR}$ and Perizin ${ }^{\oplus}$ treatments.

No of fallen mites

Group A apiaries a

Groupe B apiaries a

VA1 (5) CO1 (10) BG1 (7) BG2 (12) CO2 ${ }^{\mathrm{b}}$ (14) PV $\mathrm{V}^{\mathrm{b}}(10) V A 2^{\mathrm{c}}$ (9) $B G 3^{\mathrm{c}}$ (11)

\begin{tabular}{|c|c|c|c|c|c|c|c|c|}
\hline \multicolumn{9}{|l|}{ Apistan ${ }^{\circledR}$} \\
\hline Mean & 78 & 138 & 52 & 1117 & 68 & 39 & 14 & 304 \\
\hline SD & 80.8 & 109.4 & 72.3 & 659.9 & 133.4 & 29.3 & 19.4 & 274.6 \\
\hline $\operatorname{Min} / \max$ & $0 / 196$ & $63 / 430$ & $6 / 207$ & $186 / 2200$ & $1 / 474$ & $3 / 84$ & $1 / 64$ & $42 / 1003$ \\
\hline \multicolumn{9}{|l|}{ Perizin $^{(\mathbb{R})}$} \\
\hline Mean & 124 & 222 & 1257 & 625 & 8 & 332 & 6 & 401 \\
\hline SD & 123.3 & 95.5 & 810.1 & 978.7 & 16.3 & 256.3 & 14.8 & 271.7 \\
\hline $\mathrm{Min} / \max$ & $1 / 289$ & $78 / 361$ & $536 / 2959$ & $10 / 3500$ & $0 / 62$ & $3 / 706$ & $0 / 44$ & $39 / 892$ \\
\hline \multicolumn{9}{|l|}{ Total } \\
\hline Mean & 202 & 360 & 1309 & 1742 & 76 & 371 & 20 & 705 \\
\hline SD & 69.3 & 186.1 & 875.2 & 1406.2 & 138.7 & 265.2 & 33.7 & 529.1 \\
\hline $\operatorname{Min} / \max$ & $105 / 294$ & $183 / 791$ & $542 / 3166$ & $246 / 5700$ & $1 / 476$ & $7 / 759$ & $1 / 108$ & $81 / 1895$ \\
\hline Percentage & & & & & & & & \\
\hline $\begin{array}{l}\text { effectiveness } \\
\left.\text { of Apistan }{ }^{(}\right)\end{array}$ & 38.8 & 38.4 & 4 & 64.1 & 89.5 & 10.4 & 67.4 & 43.1 \\
\hline $\operatorname{Min} / \max$ & $0 / 99.1$ & $22.8 / 61.2$ & $1.1 / 8$ & $24.2 / 98.8$ & $52.6 / 100$ & $0.6 / 92.6$ & $59.3 / 100$ & $25.2 / 53.9$ \\
\hline
\end{tabular}

Average effectiveness of the treatment with Apistan referred to the apiary. The apiaries are subdivided in groups and localities. a Abbreviation for aplary with number of colonies in parentheses; $b$ Apiaries were treated with Perizin ${ }^{\circledR}$ in addition to Apistan ${ }^{\circledR}$ in autumn 1992. ${ }^{c}$ Apiaries were treated with amitraz in addition to Apistan ${ }^{\circledR}$ in autumn 1992

These observations of individual colony variation, together with the differences in the average effectiveness obtained in the apiaries, provide evidence for the presence of strains of $V$ jacobsoni resistant to fluvalinate in the apiaries located in Lombardy. Additional support for this conclusion comes from observations carried out by Milani (1994) on mites from Bergamo apiaries (close to BG1, BG2 and BG3 apiaries). The resistance of the mites to fluvalinate was tested in vitro on paraffin disks. The results showed a $L_{50}$ at least 10 times higher than that recorded by mites collected in apiaries in Friuli (north-east Italy), where colony mortality in apiaries treated with Apistan ${ }^{\oplus}$ has not been reported.

Many elements lead us to predict that the phenomenon may develop and spread rapidly. The data of this study must be a matter of serious concern to all beekeepers. There is a pressing and urgent need to verify the effectiveness of Apis$\tan ^{\circledR}$, throughout the shared range of $V$ jacobsoni and $A$ mellifera, as part of an acaricide-resistance management plan to safeguard beekeeping from serious damage in the future. 


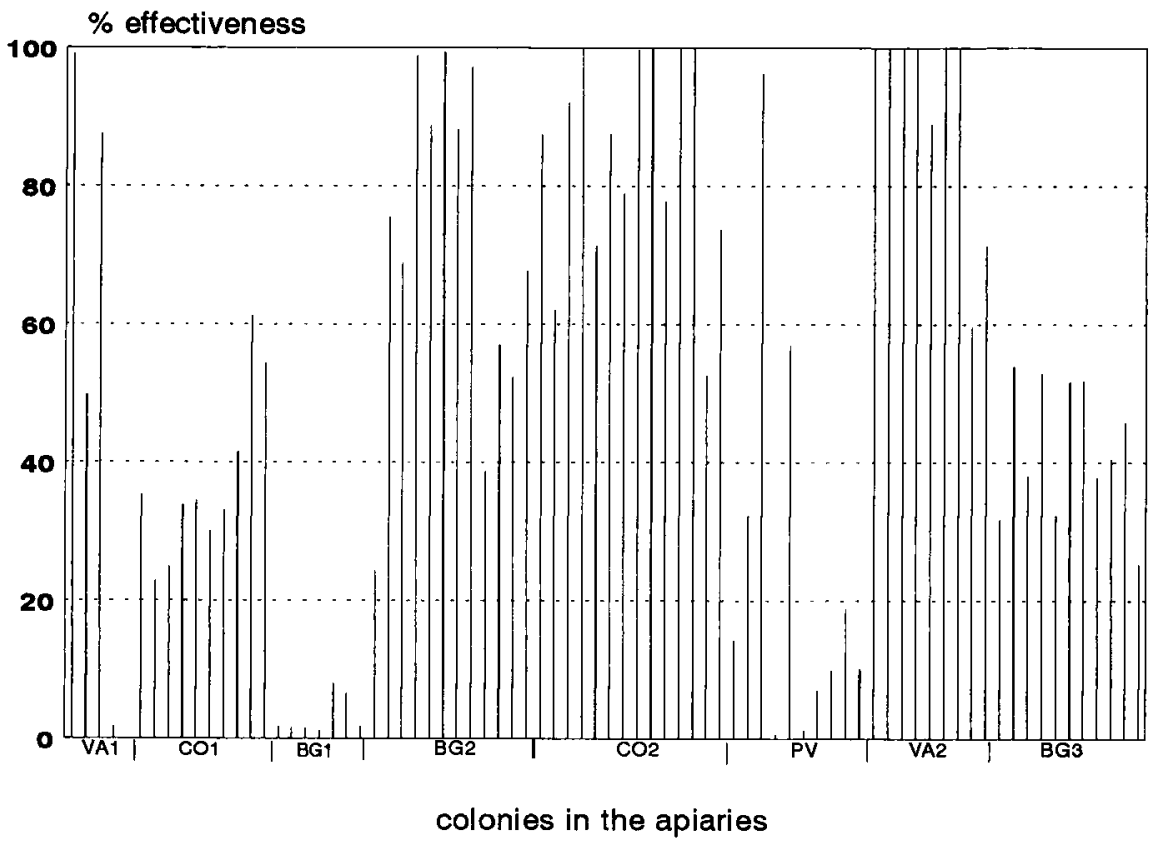

Fig 2. Effectiveness of treatment with Apistan ${ }^{\circledR}$ in single colonies by apiary.

\section{ACKNOWLEDGMENT}

The strips of Apistan ${ }^{(\boxplus)}$ were provided by Federazione Apicoltori Italiani.

Résumé - Inefficacité du traitement à l'Apistan ${ }^{\circledR}$ contre Varroa jacobsoni Oud en plusieurs régions de Lombardie (Italie). Dans plusieurs régions d'Italie on signale depuis quelques années de fortes mortalités d'abeilles dues à la varroose dans des colonies traitées à l'Apistan ${ }^{\circledR}$. Afin d'étudier ce phénomène, 78 colonies réparties en 8 localités de Lombardie (fig 1) ont été traitées à l'Apistan ${ }^{\circledR}$ durant $22 \mathrm{j}$. Lors du traitement on a procédé à un blocage de la ponte en encageant les reines. Les acariens tombés sur les plaques de dépistage ont été dénombrés tous les $8 \mathrm{j}$. Deux $\mathrm{j}$ après le retrait des lanières d'Apistan ${ }^{\circledR}$ un traitement de contrôle au Perizin ${ }^{(\circledR)}$ a été effec- tué. La faible efficacité générale du traitement (tableau I) et les grandes différences entre ruchers mais aussi entre ruches d'un même rucher (fig 2) prouvent la présence de souches de $V$ jacobsoni résistantes à l'Apistan ${ }^{\circledR}$ et leur diffusion au sein des populations de Lombardie.

Apis mellifera / Varroa jacobsoni / efficacité traitement / fluvalinate / sensibilité-résistance

Zusammenfassung - Unwirksame Behandlung der Varroose durch Apistan ${ }^{\circledR}$ in einigen Provinzen der Lombardei (Italien). In einigen italienischen Gegenden wurden seit mehreren Jahren hohe Bienenverluste durch die Varroose gemeldet. Die betroffenen Völker waren mit Apistan ${ }^{\circledR}$ behandelt worden. Zur Untersuchung dieser Berichte wurden an 8 verschiedenen 
Orten in der betroffenen Region Lombardei insgesamt 78 Völker mit Apistan ${ }^{\circledR}$ behandelt (Abb 1). Die Behandlungsdauer betrug 22 Tage. Zu Beginn der Behandlung wurden die Königinnen gesperrt, sodaß am Ende der Behandlung keine Brut mehr vorhanden war. Während der Behandlung wurden alle 8 Tage die abgetöteten Milben auf den Bodeneinlagen ausgezählt. Zur Bestimmung des verbleibenden Befalls wurden die Völker zwei Tage nach Entfernung der Apistanstreifen mit Perizin ${ }^{\circledR}$ behandelt. Der insgesamt niedrige Behandlungserfolg (Tabelle I) und die grossen Unterschiede zwischen den Bienenständen, aber auch zwischen den einzelnen Völkern eines Standes ( $A b b$ 2) weisen auf das Vorhandensein und die Ausbreitung von gegen Fluvalinat resistenten Varroa jacobsoni-Linien in der Lombardei hin.

\section{Apis mellifera / Varroa jacobsoni / Flu- valinate / Wirksamkeit / Resistenz}

\section{REFERENCES}

Arcuelo P, Gąllo C, Genduso P (1989) Comparative tests with fluvalinate, coumaphos, amitraz and semiochemicals (Econome) against Varroa jacobsoniOud. in: Present Status of Varroatosis in Europe and Progress in Varroa Mite Control (Cavalloro R, ed) CEC, Luxembourg, 311-314

Arcuelo P, Vitale F, Caracappa (1993) Efficacia dei trattamenti con acido formico e fluvalinate contro Varroa jacobsoniOud. Apic Mod 83, 185-192

Barbattini R (1981) Un nuovo temibile acaro parassita delle api. Inform Agrar 37, 16769-16770

Barbattini R, Greatti M (1992) Verifica del piano di controllo di Varroa jacobsoni in Friuli-Venezia Giulia. L'Ape Nostra Amica 6, 7-13

Barbattini R, Milani N, Chiesa F, D'Agaro M (1989) Field trials with different acaricides in north-east Italy: effectiveness against Varroa jacobsoniOud and tolerance by bees. In: Present Status of Varroatosis in Europe and Progress in Varroa Mite Control (Cavalloro R, ed) CEC, Luxembourg, 347-354

Borneck R, Merle B (1989) New tests for varroa control with Apistan (Fluvalinate). In: Present Status of Varroatosis in Europe and Progress in Varroa Mite Control (Cavalloro R, ed) CEC, Luxembourg, 315-330
Borneck R, Merle B (1990) Essais sur Apistan en 1988. Apiacta 25, 16-25

De Ruijter A, Van Den Eijnde J (1989) Field experiment to determine the efficacity of Apistan on varroa mites in bee colonies and the effect on spring development of treated colonies. In: Present Status of Varroatosis in Europe and Progress in Varroa Mite Control (Cavalioro R, ed) CEC, Luxembourg, 331-337

Ferrer-Dufol M, Martinez-Viñuales Al, Sanchez-Acedo C (1991) Comparative tests of fluvalinate and flumethrin to control Varroa jacobsoni Oudemans. J Apic Res 30, 103-106

Frediani D (1993) Resistenza della varroa all'Apistan... ma siamo proprio sicuri? Apitalia 9, 16-17

Frilli F (1989) Varroatosis situation in Italy. In: Present Status of Varroatosis in Europe and Progress in Varroa Mite Control (Cavalloro R, ed) CEC, Luxembourg, 37-38

Frilli F, Milani N, Barbattini Ret al (1992) Prove di lotta contro Varroa jacobsonicon diversi prodotti ad effetto acaricida: efficacia e tollerabilità da parte delle api. In: Stato attuale e sviluppo della ricerca in apicoltura. (Prota R, Floris I, eds), Istituto di Entomologia Agraria Sassari, 59-78

Greatti M, Barbattini R, Frilli F (1992/93) Verifica dell'efficacia di Apistan (pa fluvalinate) nei confronti di Varroa jacobsoni Oud in Provincia di Trieste. Apicoltura 8, $17-26$

Lendaro D, Tonelli S (1985) Nozioni pratiche di diagnosi e trattamento della varroasi. Consorzio tra gli apicoltori della provincia di Udine, via Diaz, 58, 33100 Udine

Llorente Martinez JF (1989) Treatment with a contact acaricide to control Varroa jacobsoni. In: Present Status of Varroatosis in Europe and Progress in Varroa Mite Control (Cavalloro R, ed) CEC, Luxembourg, 355-360

Llorente Martinez JF, Robles Portela E, Salvachoa Gallego JC (1989) Ensayo sobre la eficacia del acaricida fluvalinato (Apistan) contra la varroasis de la abeja melifera en presencia de cria. Cuad Apic 6 , 14-16

Loglio G (1993) Varroa jacobsoni Oud: comparsa di resistenza al fluvalinate? Apic Mod 84, 7-10

Loglio G, Plebani G (1992) Valutazione dell'efficacia dell'Apistan. Apic Mod 83, 95-98

Milani N (1994) Possible presence of fluvalinate-resistant strains of Varroa jacobsoni in northern Italy. In: New Perspective on Varroa jacobsoni Rez, Praga (in press)

Milani N, Barbattini R (1988) Effectiveness of Apistan (fluvalinate) in the control of Varroa jacobsoni Oudemans and its tolerance by Apis mellifera Linnaeus. Apicoltura 4, 39-58

Watkins M (1993) Apiberia 93. Posibles resistencias de Varroa. Vida Apic 62, 9-10 